Report

\title{
Comparison of breast cancer mucin (BCM) and CA 15-3 in human breast cancer
}

\author{
M.B. Garcia, M.A. Blankenstein, E. van der Wall ${ }^{1}$, J.W.R. Nortier ${ }^{1}$, J.H. Schornagel ${ }^{2}$, and J.H.H. Thijssen \\ Department of Endrocinology and ${ }^{2}$ Medical Oncology Unit, Academic Hospital Utrecht, \\ and ${ }^{I}$ Department of Internal Medicine, Diakonessen Hospital Utrecht, The Netherlands
}

Key words: BCM, breast cancer, CA 15-3, CEA, mucin, tumour markers

\section{Summary}

The Breast Cancer Mucin (BCM) enzyme immunoassay utilizes two monoclonal antibodies (Mab), M85/34 and $F 36 / 22$, for the identification of a mucin-like glycoprotein in serum of breast cancer patients. We have compared BCM with CA 15-3, another member of the human mammary epithelial antigen family.

Serum BCM was evaluated in 151 and CA 15-3 in 134 patients with breast cancer, in 30 normal controls, in 9 pregnant women, and in 13 cancer patients (non-breast). Neither the normal controls nor the pregnant women had BCM levels $>25 \mathrm{U} / \mathrm{ml}$. In contrast, 87 of 115 patients $(75 \%)$ with metastatic breast cancer had $\mathrm{BCM}$ levels $>25 \mathrm{U} / \mathrm{ml}$. All control persons had CA 15-3 levels $<25 \mathrm{U} / \mathrm{ml}$, but 2 out of 9 pregnant women $(22 \%)$ had levels $>25 \mathrm{U} / \mathrm{ml}$. Seventy-four out of 97 patients $(76 \%)$ with metastatic breast cancer had CA 15-3 levels $>25 \mathrm{U} / \mathrm{ml}$.

A statistically significant correlation was found between BCM and CA 15-3 in the breast cancer patient group $(r=0.883, p<0.001, n=134)$ and in the normal control group $(r=0.743, p<0.001, n=30)$. $B C M$ and CA 15.3 both showed no correlation with CEA in breast cancer patients $(r=0.060, n=81$; and $r=$ $0.146, \mathrm{n}=78$, respectively). BCM had a range of sensitivity similar to that of the CA 15-3 RIA.

Our results suggest that BCM may be a useful new marker for monitoring the clinical course of patients with breast cancer. Furthermore, in the evaluation of breast cancer patients, marker pands depending on disease stage may be a better choice than any single parameter in the evaluation of breast cancer patients.

\section{Introduction}

An ideal tumour marker should have both high specificity and sensitivity, and thus have a potential role in screening, diagnosis, and staging, and in the follow up of patients during the course of their disease.

In women with breast cancer the measurement of tumour marker serum levels may be useful in the follow up of the disease [1-4]. However, in primary breast cancer the 'classical' tumour marker carcinoembryonic antigen (CEA) is poorly correlated with disease spread and clinical course [3-5]. Therefore new tumour markers have been developed.

Several clinical studies $[5,6]$ have suggested that CA $15-3$ is a more sensitive marker than CEA in the follow-up of patients with metastatic breast cancer. Some authors advise the use of both CEA and CA $15-3$ for better monitoring of these patients 
(e.g. 7). By contrast, however, in a recent study no advantage was seen by adding CEA to CA 15-3 [5]. Therefore, tumour markers with higher sensitivity and specificity than CA 15-3 are urgently needed in the management of metastatic breast cancer.

The monoclonal antibodies M85/34 and the F36/ 22 were found to identify a mucin-like glycoprotein, breast cancer mucin (BCM), in serum of breast cancer patients. The protein originates from ductal epithelial tissue. Mab F36/22 reacts with the human breast cancer cell line MCF-7 and with the ductal carcinoma antigen (DCA), another member of the human mammary epithelial (HME) family of glycoproteins [8-14].

The present study was designed to compare CA 15-3 and BCM levels in serum samples from healthy persons and breast cancer patients and to evaluate which of these markers, either alone or in combination with CEA, has the higher sensitivity and specificity.

\section{Materials and methods}

\section{Serum samples}

Serum samples were obtained from patients attending the out-patient clinics of both hospitals. They were stored at $-20^{\circ} \mathrm{C}$ until assay. Additional samples were retrieved from our serum bank which is kept at $-70^{\circ} \mathrm{C}$; mean levels of $\mathrm{BCM}$ and $\mathrm{CA}$ 15-3 in these samples were not different from those in the fresh samples. Therefore the combined use of freshly frozen and long-term frozen samples was considered to be justified. Samples from healthy blood donors were provided by the Utrecht Red Cross blood bank.

\section{Clinical information}

Clinical staging was carried out according to the criteria of the International Union Against Cancer (UICC) and the American Joint Commission in Cancer Staging and Results Reporting Classifications (AJC) [15]. On the basis of the available clinical data the patients were grouped as follows: 21 patients in stage I; 3 patients in stage II; 5 patients in stage III; 115 patients in stage IV; 7 patients stage unknown; 30 healthy blood donors (age
$34 \pm 9$ years); 9 pregnant women; 13 non-breast cancer patients.

\section{Assay of tumour markers}

$\mathrm{BCM}$ was measured in serum with a solid phase enzyme immunoassay (EIA) provided by Abbott Laboratories (Chicago, IL, USA). Polystyrene beads coated with Mab M85/34 [12] were incubated with standards, controls, and 1: 11 diluted serum specimens for $2 \mathrm{~h}$ at $37^{\circ} \mathrm{C}$. The incubation buffer contained neuraminidase to liberate sialic acid residues and to expose the carbohydrate epitope. Unbound material was removed by aspiration of fluid followed by two washings of the beads with distilled water by the Pentawash device. After washing, Mab F36/22 [8] conjugated with horse radish peroxidase was incubated with the beads for $2 \mathrm{~h}$ at $37^{\circ} \mathrm{C}$. Unbound conjugate was removed by aspiration and the beads were washed again. The beads were next incubated with hydrogen peroxide and orthophenylene diamine- $\mathrm{HCl}$ at room temperature for 30 minutes. The reaction was stopped by the addition of $1 \mathrm{~N}$ sulfuric acid, and absorbance was read at $492 \mathrm{~nm}$ using the Abbott Quantum spectrophotometer which also performed the calculations. The intra-assay coefficient of variation was $9 \%$ at $20 \mathrm{U} / \mathrm{ml}(\mathrm{n}=2)$, and $7 \%$ at $150 \mathrm{U} / \mathrm{ml}$ $(\mathrm{n}=8)$; the inter-assay coefficient of variation was $10 \%$ at $200 \mathrm{U} / \mathrm{ml}(\mathrm{n}=4)$. All samples were tested in duplicate. The variation in duplicates was 5.7, $6.2,6.2,5.0$, and $4.6 \%$ for samples containing $<25,25-50,50-100,100-150$, and $150-200 \mathrm{U} / \mathrm{ml}$ respectively.

CA 15-3 was estimated in serum with an immunoradiometric assay (IRMA), using reagents purchased from Centocor (Malvern, USA). The IRMA utilizes two monoclonal antibodies (115D8, DF3) which probably recognize different epitopes of the same antigen. Inter-assay variation determined from control samples supplied with the kits was $8 \%$ at $38 \mathrm{U} / \mathrm{ml}(\mathrm{n}=39)$. BCM and CA $15-3$ determinations were performed simultaneously.

$\mathrm{CEA}$ was assayed by enzyme immunoassay (Abbott Laboratories, Chicago, IL, USA). Inter-assay variation determined from control samples supplied with the kits was $10 \%$ at $2.6 \mathrm{ng} / \mathrm{ml}(\mathrm{n}=14)$ and $4 \%$ at $15.3 \mathrm{ng} / \mathrm{ml}(\mathrm{n}=14)$. 


\section{Statistical evaluation}

Data were evaluated with the coefficient of correlation and Wilcoxon's rank-sum test [16]. P-values below 0.05 were considered to reflect statistical significance.

\section{Results}

Serum tumour marker concentrations obtained are summarized in Table 1.

\section{Breast cancer mucin}

There was no statistically significant difference between men and women of the normal control group. The 97.5 th percentile value $(25 \mathrm{U} / \mathrm{ml})$ was chosen as positive/negative cut-off. None of the normal controls had values above $25 \mathrm{U} / \mathrm{ml}$ (Table 2, Fig. 1). Similarly none of the pregnant women had BCM levels $>25 \mathrm{U} / \mathrm{ml}$ (Table 2) which further illustrates the specificity of BCM-EIA. Differences between pregnant women and non-pregnant controls were not statistically significant.

Patients with breast cancer exhibited a wide range of circulating levels of BCM (Table 1, Fig. 1). The incidence of elevated values for this group was $65 \%$. Only $33.5 \%$ of values observed in patients with Stage I breast cancer were elevated, whereas in patients with stage IV, BCM levels were elevat- ed in $75 \%$ (Table 2 ). In patients with bone metastases $66 \%$ of $\mathrm{BCM}$ values were $>50 \mathrm{U} / \mathrm{ml}$ (Table 2 ), whereas $15 \%$ of the patients had normal levels. In patients with hepatic metastases BCM levels of $888 \pm 423 \mathrm{U} / \mathrm{ml}$ (mean $\pm \mathrm{SEM}$ ) were found. None of these patients had normal BCM values. The sera from 13 patients with other malignancies were evaluated. Results are given in Table 3. Only two patients $(15 \%)$ had elevated values (one ovarian cancer $81 \mathrm{U} / \mathrm{ml}$ and one lung cancer $50 \mathrm{U} / \mathrm{ml}$ ).

\section{CA 15-3}

The mean serum levels ( \pm SEM) of CA 15-3 in the healthy blood donor group were $14 \pm 1 \mathrm{U} / \mathrm{ml}$. All CA $15-3$ values were below $25 \mathrm{U} / \mathrm{ml}$. The 97.5 th percentile of CA 15-3 values in control samples was $24 \mathrm{U} / \mathrm{ml}$. For practical purposes, therefore, $25 \mathrm{U} /$ $\mathrm{ml}$ was chosen as a cut-off value between normal and elevated CA 15-3.

The CA 15-3 values in pregnant women were $20 \pm 2 \mathrm{U} / \mathrm{ml}$ (mean $\pm \mathrm{SEM}$ ). Two of the $9 \mathrm{preg}-$ nant women had elevated CA 15-3 levels.

CA 15-3 was determined in sera from 134 breast cancer patients. Elevated levels were found in $65 \%$ of these patients. In $50.5 \%$ of these samples levels even exceeded $50 \mathrm{U} / \mathrm{ml}$ (Tables 1 and 2). Similar to $\mathrm{BCM}$, the percentage of elevated values increased with stage of the disease (Table 2). In patients with bone metastases CA $15-3$ values of $324 \pm 80 \mathrm{U} / \mathrm{ml}$

Table 1. Breast Cancer Mucin, CA 15-3, and CEA in serum

\begin{tabular}{|c|c|c|c|c|c|c|c|c|c|c|c|c|c|}
\hline \multirow[t]{2}{*}{ Group } & \multicolumn{4}{|c|}{$\mathrm{BCM}(\mathrm{U} / \mathrm{ml})$} & \multicolumn{4}{|c|}{ CA $15-3(\mathrm{U} / \mathrm{ml})$} & \multicolumn{5}{|c|}{$\mathrm{CEA}(\mathrm{ng} / \mathrm{ml})$} \\
\hline & $\mathrm{n}$ & Mean \pm & SEM & Range & $\mathrm{n}$ & Mean \pm & \pm SEM & I Range & $\mathrm{n}$ & Mean \pm & SEM & Rar & Inge \\
\hline \multicolumn{14}{|l|}{ Normal control } \\
\hline group & 30 & $13 \pm$ & 1 & $5-23$ & 30 & $14 \pm$ & 1 & $6-24$ & 30 & $1.7 \pm$ & 0.3 & 0.01 & $1-\quad 5.5$ \\
\hline Pregnant women & 9 & $14 \pm$ & 3 & $2-23$ & 9 & $20 \pm$ & 2 & $14-29$ & 9 & $0.6 \pm$ & 0.1 & 0.23 & $3-\quad 1.2$ \\
\hline \multicolumn{14}{|l|}{ Patients with } \\
\hline other malignancies & 13 & $23 \pm$ & 6 & $4-81$ & 13 & $26 \pm$ & 5 & $8-76$ & & & & & \\
\hline \multicolumn{14}{|l|}{ Patients with } \\
\hline breast cancer & 151 & $190 \pm$ & 46 & $0-3564$ & 134 & $214 \pm$ & 42 & $0-2960$ & 81 & $28 \pm$ & 11 & 0 & -600 \\
\hline Stage I & 21 & $28 \pm$ & 9 & 4- 174 & 21 & $34 \pm$ & 12 & $7-270$ & 12 & $1.3 \pm$ & 0.25 & 0.1 & -3 \\
\hline Stage IV & 115 & $243 \pm$ & 59 & $0-3564$ & 97 & $259 \pm$ & 54 & $0-2960$ & 61 & $25 \pm$ & 10 & 0 & -600 \\
\hline bone metastases & 52 & $297 \pm$ & 92 & $1-3564$ & 46 & $324 \pm 8$ & 80 & $5-2960$ & 42 & 27 & 14 & 0 & -600 \\
\hline hepatic metastases & 10 & $888 \pm 4$ & 423 & $28-3564$ & 10 & $864 \pm 30$ & 305 & $19-2960$ & 10 & 20 & 11 & 1 & -229 \\
\hline
\end{tabular}




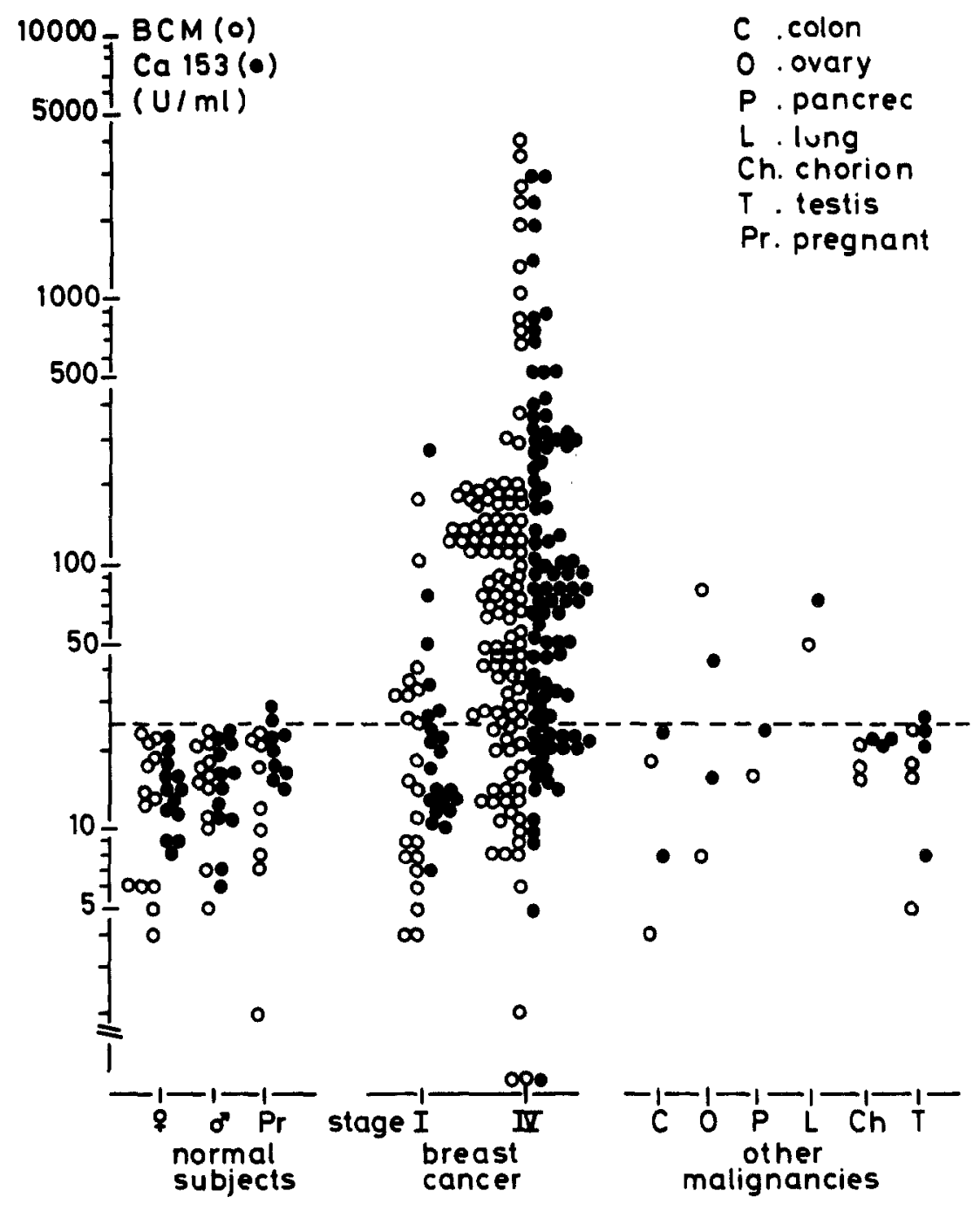

Fig. 1. Serum levels of Breast Cancer Mucin (BCM) and $\mathrm{Ca} \mathrm{15-3} \mathrm{in} \mathrm{individual} \mathrm{samples} \mathrm{from} \mathrm{healthy} \mathrm{persons} \mathrm{and} \mathrm{patients} \mathrm{with} \mathrm{different}$ malignancies.

were found. Values of more than $50 \mathrm{U} / \mathrm{ml}$ were found in $69 \%$ of these patients. Only 8 patients had normal serum levels. Remarkably, four of these patients were in clinical remission. In patients with hepatic metastases the CA 15-3 values were even higher $(864 \pm 305)$. Ninety per cent of these patients had levels $>50 \mathrm{U} / \mathrm{ml}$ (Tables 1 and 2).

Three out of 13 patients with malignancies of other organs (23\%) had elevated CA $15-3$ values (one ovarian cancer $42 \mathrm{U} / \mathrm{ml}$, one testicular cancer $26 \mathrm{U} / \mathrm{ml}$, and one lung cancer $76 \mathrm{U} / \mathrm{ml}$ ).
$C E A$

In 81 of the patients with breast cancer, the serum levels of CEA were also measured. The results are shown in Table 1. The mean serum level ( \pm SEM) in the healthy blood donor group was $1.70 \mathrm{ng} / \mathrm{ml}$ $( \pm 0.26)$. Three $\mathrm{ng} / \mathrm{ml}$ was used a cut-off value between normal and elevated values. Thirteen per cent of the donors had elevated levels. This might be related to their smoking habits. These were not known, however. CEA values in pregnant women were $0.62 \mathrm{ng} / \mathrm{ml}( \pm 0.12)$. All patients with Stage I breast cancer had normal values. 
Table 2. Distribution of BCM and CA 15-3 in patients with breast cancer and in three control groups [n(\%)]

\begin{tabular}{|c|c|c|c|c|c|c|c|c|c|c|}
\hline \multirow[t]{2}{*}{ Group } & \multicolumn{5}{|c|}{$\mathrm{BCM}(\mathrm{U} / \mathrm{ml})$} & \multicolumn{5}{|c|}{ CA $15-3(\mathrm{U} / \mathrm{ml})$} \\
\hline & $\mathrm{n}$ & $<25$ & $25-50$ & $50-100$ & $>100$ & $\mathbf{n}$ & $<25$ & $25-50$ & $50-100$ & $>100$ \\
\hline Normal control group & 30 & $30(100 \%)$ & & & & 30 & $30(100 \%)$ & & & \\
\hline Pregnant women & 9 & $9(100 \%)$ & & & & 9 & $7(78 \%)$ & $2(22 \%)$ & & \\
\hline Patients with other malignancies & 13 & $11(85 \%)$ & & $2(15 \%)$ & & 13 & $10(77 \%)$ & $2(15 \%)$ & $1(8 \%)$ & \\
\hline Patients with breast cancer & 151 & $52(34 \%)$ & $32(21 \%)$ & $17(11 \%)$ & $50(33 \%)$ & 134 & $47(35 \%)$ & $19(14 \%)$ & $22(17 \%)$ & $44(33 \%)$ \\
\hline Stage I & 21 & $14(66 \%)$ & $5(24 \%)$ & & $2(9 \%)$ & 21 & $15(71 \%)$ & $4(19 \%)$ & $1(5 \%)$ & $1(5 \%)$ \\
\hline Stage IV & 115 & $28(24 \%)$ & $24(21 \%)$ & $16(14 \%)$ & $47(41 \%)$ & 97 & $23(24 \%)$ & $13(13 \%)$ & $21(22 \%)$ & $40(41 \%)$ \\
\hline bone metastases & 52 & $8(15 \%)$ & $10(19 \%)$ & $4(8 \%)$ & $30(58 \%)$ & 46 & $8(17 \%)$ & $6(13 \%)$ & $8(17 \%)$ & $24(52 \%)$ \\
\hline hepatic metastases & 10 & & $2(20 \%)$ & $2(20 \%)$ & $6(60 \%)$ & 10 & $1(10 \%)$ & & $2(20 \%)$ & $7(70 \%)$ \\
\hline
\end{tabular}

\section{Comparison between tumour markers}

In all groups of patients studied a significant correlation between BCM and CA 15-3 levels was found (Table 4). The correlations between BCM and CEA $(r=0.060, p>0.1, n=81)$ and between CA $15-3$ and $\operatorname{CEA}(r=0.146, p>0.1, n=78)$ were poor.

The sensitivity and specificity of CA 15-3, BCM, and CEA were determined either alone or in combination. Sensitivity is defined as positivity in disease and expressed as per cent ([true positives (true positives + false negatives)] $\times 100$ ); specificity is defined as negativity in health or absence of a particular disease and is also expressed as per cent ([true negatives (true negatives + false posi- tives)] $\times 100$ ). The results are shown in Table 5 and illustrate the superiority of $\mathrm{BCM}$ and $\mathrm{CA} 15-3$ over CEA, as well as the similarity of BCM and CA 15-3.

\section{Discussion}

Early detection of disease progression may be important in the management of patients with breast cancer. Tumour markers have been widely studied in breast cancer, since a biochemical signal was thought to be the best possibility for detecting any subclinical spread of the disease. Carcino Embryonic Antigen (CEA) was found to be useful only in a limited number of cases in early detection

Table 3. Tumour markers in patients with other malignancies

\begin{tabular}{|c|c|c|c|c|c|}
\hline Tumour site & Remarks & $\begin{array}{l}\text { BCM } \\
(\mathrm{U} / \mathrm{ml})\end{array}$ & $\begin{array}{l}\text { CA 15-3 } \\
(\mathrm{U} / \mathrm{ml})\end{array}$ & $\begin{array}{l}\text { CEA } \\
(\mathrm{ng} / \mathrm{ml})\end{array}$ & $\begin{array}{l}\text { CA-125 } \\
(\mathrm{U} / \mathrm{ml})\end{array}$ \\
\hline Colon & Progression, hepatic meta's & 18 & 24 & 60 & \\
\hline Colon & Hepatic meta's, after chemotherapy & 4 & 8 & 6.7 & \\
\hline Ovary & Stage IV & 81 & 42 & 1.2 & \\
\hline Ovary & Stage III during chemotherapy & 8 & 16 & & 78 \\
\hline Testis & Stage IV, progression & 8 & 22 & & \\
\hline Testis & Stage III, progression & 18 & 8 & & \\
\hline Testis & Stage I, stable & 5 & 26 & & \\
\hline Testis & Stage IIc & 24 & 24 & & \\
\hline Chorion & & 16 & 22 & & \\
\hline Chorion & & 16 & 22 & & \\
\hline Chorion & & 22 & 21 & & \\
\hline Pancreas & Progression & 16 & 24 & & \\
\hline Lung & Progression & 50 & 76 & 19 & \\
\hline
\end{tabular}


Table 4. Linear correlation between serum levels of BCM and CA 15-3

\begin{tabular}{lrll}
\hline Samples & $\mathrm{n}$ & $\mathrm{r}$ & $\mathrm{p}$-value \\
\hline Normal controls & 30 & 0.743 & $\mathrm{p}<0.001$ \\
$\begin{array}{l}\text { Pregnant women } \\
\text { Patients with }\end{array}$ & 9 & 0.768 & $\mathrm{p}<0.05$ \\
other malignancies & & & \\
Patients with breast cancer & 13 & 0.745 & $\mathrm{p}<0.05$ \\
Stage I & 134 & 0.883 & $\mathrm{p}<0.001$ \\
Stage IV & 21 & 0.847 & $\mathrm{p}<0.001$ \\
bone metastases & 97 & 0.932 & $\mathrm{p}<0.001$ \\
hepatic metastases & 46 & 0.954 & $\mathrm{p}<0.001$ \\
& 10 & 0.950 & $\mathrm{p}<0.001$ \\
\hline
\end{tabular}

of progressive disease [1]. Using the methodology of cell hybridization, a large number of monoclonal antibodies was raised against breast cancer tissue or breast cancer cells $[17,18]$.

CA 15-3 has already been shown to be more sensitive than CEA in patients with metastatic carcinoma of the breast $[5,6]$. Another enzyme immunoassay has been developed by using the Mab M85/ 34 and the Mab M36/22. These monoclonal antibodies are raised against breast cancer cells and recognize the mucin-like glycoprotein $\mathrm{BCM}$, a member of the HME family of glycoproteins [813]. In the present study BCM was detectable in sera of breast cancer patients, patients with other malignancies, normal controls, and pregnant women, suggesting that the antigen is not tumour-specific. In the sera of breast cancer patients BCM levels were found to be significantly higher than in the three other groups (Table 1).
Serum BCM levels appeared not to be related to age or menopausal status. BCM and CA 15-3 serum levels were well correlated. Differences might be expected since the BCM assay detects a carbohydrate epitope exposed following neuraminidase treatment, while the CA $15-3$ assay identifies a polypeptide epitope. The high degree of similarity observed suggests that the two epitopes are closely related. The final decision in this matter, where two assays which utilize four different antibodies are compared, must await complete characterization of the epitopes. Therefore several analogies were expected between these two assays. BCM concentrations are directly related to the stage of disease and to some extent to the site of metastasis.

In two of the thirteen patients with malignancies of the other organs, the levels of BCM and CA 15-3 were elevated. One of these patients had an ovarian carcinoma Stage IV (BCM: $81 \mathrm{U} / \mathrm{ml}$; CA 15-3: $42 \mathrm{U} / \mathrm{ml}$ ), while the other had lung carcinoma in clinical progression (BCM: $50 \mathrm{U} / \mathrm{ml}$; CA 15-3: $76 \mathrm{U} / \mathrm{ml}$ ). An explanation could be that Mab F36/ 22 reacts against ductal carcinoma antigens which are also present in other carcinomas $[19,20]$. In one other patient with ovarian carcinoma, however, BCM and CA 15-3 were not elevated in spite of high levels of CA $125(78 \mathrm{U} / \mathrm{ml})$.

The observation that sera from apparently healthy individuals contain immunoreactive $\mathrm{BCM}$ and CA $15-3$ is remarkable. Burchel et al. [21] using Western blotting could not detect mucin epithelial antigens in sera which were positive by immunoassay. Several possibilities appear to be able to ac-

Table 5. Sensitivity and specificity of tumour markers

\begin{tabular}{|c|c|c|c|c|c|}
\hline \multirow[t]{2}{*}{ Markers } & \multicolumn{2}{|l|}{ Specificity (\%) } & \multicolumn{3}{|c|}{ Sensitivity (\%) } \\
\hline & Contr + Preg & $\mathrm{NBC}$ & Tot.BC & Stage I & Stage IV \\
\hline BCM (cut-off value $25 \mathrm{U} / \mathrm{ml}$ ) & 100 & 85 & 64 & 33 & 76 \\
\hline CA $15-3$ (cut-off value $25 \mathrm{U} / \mathrm{ml}$ ) & 95 & 77 & 64 & 29 & 76 \\
\hline CEA (cut-off value $3 \mathrm{ng} / \mathrm{ml}$ ) & 92 & - & 52 & 8 & 61 \\
\hline $\mathrm{BCM}+\mathrm{CA} 15-3$ & 95 & 77 & 70 & 38 & 78 \\
\hline $\mathrm{BCM}+\mathrm{CEA}$ & 90 & - & 74 & 33 & 84 \\
\hline CA $15-3+$ CEA & 85 & - & 72 & 33 & 83 \\
\hline $\mathrm{BCM}+\mathrm{CA} 15-3+\mathrm{CEA}$ & 85 & - & 77 & 33 & 86 \\
\hline
\end{tabular}

Contr $=$ blood donors, Preg $=$ pregnant women, $\mathrm{NBC}=$ other malignancies, Tot. $\mathrm{BC}=$ all patients with breast cancer. 
count for this phenomenon, i.e. background values due to assay conditions, or release of different antigens in malignant states and health [22].

In the control group BCM was shown to have the highest $(100 \%)$ specificity when compared with CA 15-3 and CEA. In breast cancer patients with stage I BCM + CA 15-3 showed the highest sensitivity $(38 \%)$. For stage IV breast cancer patients the highest sensitivity $(86 \%)$ was obtained with a combination of BCM, CA 15-3, and CEA (Table 5).

The following conclusions can be drawn:

- BCM is detectable in sera from breast cancer patients as well as in a normal control group, in pregnant women, and in patients with other malignancies. The values for Stage IV breast cancer patients were found to be higher than in the three other groups as well as in patients with early breast cancer.

- The highest values of BCM are found in patients with bone and hepatic metastases.

- The correlation between BCM and CA 15-3 was statistically significant in all four groups studied.

- The concentrations of BCM and CA 15-3 did not show any correlation with CEA.

- BCM appeared to be as sensitive as CA 15-3 in patients with metastatic breast cancer.

- The optimal combination of tumour markers depended on the stage of the disease (Table 5). The degree of specificity in control persons was as follows: BCM (100\%), CA 15-3 (95\%), $\mathrm{BCM}+\mathrm{CA} 15-3(95 \%), \mathrm{CEA}(92 \%), \mathrm{BCM}+$ CEA (90\%), CA $15-3+\mathrm{CEA}(85 \%), \mathrm{BCM}+$ CA $15-3+$ CEA (85\%). Sensitivity in breast cancer patients increased as follows: CEA $(52 \%), \mathrm{CA} 15-3=\mathrm{BCM}(64 \%), \mathrm{BCM}+\mathrm{CA}$ 15-3 (70\%), CA $15-3+\mathrm{CEA}(72 \%), \mathrm{BCM}+$ CEA $(74 \%), \mathrm{BCM}+\mathrm{CA} 15-3+\mathrm{CEA}(77 \%)$. For stage I breast cancer the highest sensitivity $(38 \%)$ was obtained with a combination of BCM and CA 15-3; for stage IV the optimal combination was $\mathrm{BCM}+\mathrm{CA} 15-3+\mathrm{CEA}$ $(86 \%)$.

- Neither marker is $100 \%$ specific for breast cancer, as elevated values were also observed in patients with ovarian and lung cancer.

- BCM and CA 15-3 appeared to have little addi- tive value. The sensitivity of $\mathrm{BCM}$ was not higher than that of CA 15-3.

\section{Acknowledgements}

This study was supported by Abbott Laboratories, Wiesbaden, FRG. We wish to express our thanks to Dr. L. Lennartz (Abbott, FRG), and to the members of the Laboratory of Endocrinology, Academic Hospital Utrecht, for expert technical assistance.

\section{References}

1. Steward AM, Nixon D, Zamcheck N, Aisenberg A: Carcinoembryonic Antigen in breast cancer patients: serum levels and disease progress. Cancer 33: 1246-1252, 1974

2. Neville AM, Patel S, Capp M, Laurence JR, Cooper EH, Turberville $\mathrm{C}$, Coombes $\mathrm{RC}$ : The monitoring role of plasma CEA alone and in association with other tumor markers in colorectal and mammary carcinoma. Cancer 42: 14481451,1978

3. Tormey DC, Waalkes TP: Clinical correlation between CEA and breast cancer. Cancer 42: 1507-1511, 1978

4. Waalkes TP, Enterline JP, Shaper JH, Abeloff MD, Ettinger DS: Biological markers for breast carcinoma. Cancer 53: 644-651, 1984

5. Delarue JC, Mouriesse H, Dubois F, Friedman S, MayLevin F: Markers in breast cancer: does CEA add to the detection by CA 15-3? Breast Cancer Res Treat 11: 273276, 1988

6. Safi F, Beger HG, Kreibich M, Roscher R: Clinical relevance of the tumour marker CA 15-3 in breast cancer. Bresciani F, King RJB, Lippman ME, Raynaud JP (eds). Progress in Cancer Research and Therapy 35: Hormones and Cancer 3. Raven Press, New York, 1988, pp 290-293

7. Perey L, van Melle G, Bauer J, Leyvraz S, Lemarchand Th, Reymond M, Mach JP: Evaluation of CEA, CA 15-3 and CA 125 in monitoring the clinical course of metastatic breast cancer ECCO 1989, Abstract 0-170

8. Papsidero LD, Croghan GA, O'Connell MJ, Valenzuela LA, Nemoto T, Chu TM: Monoclonal antibodies (F36/22 and M7/105) to human breast carcinoma. Cancer Res 43 : 1741-1747, 1983

9. Papsidero LD, Nemoto T, Croghan GA, Chu TM: Expression of Ductal Carcinoma Antigen in breast cancer sera as defined using monoclonal antibody $F$ 36/22. Cancer Res 44 : 4653-4657, 1984

10. Papsidero LD, Johnson EA: Physicochemical purification and immunological characteristics of Ductal Carcinoma Antigen. Int J Cancer 37: 697-703, 1986 
11. Ceriani RL, Thompson K, Peterson JA, Abraham S: Surface differentiation antigens of human mammary epithelial cells carried on the human milk-fat globule. Proc Natl Acad Sci USA 74: 582-586, 1977

12. Anderson B, Slota J, Kundu S, Patrick J, Manderino G, Rittenhouse $\mathrm{H}$, Tomita J: Characterization of monoclonal antibodies to paragloboside (PG) and sialosyl-PG (2,6SPG), and an improved chromatogram binding assay for rapidly identifying antibodies to tumour antigens. J Cell Biochem 157, 1987

13. Peterson JA, Case Buehring G, Taylor-Papadimitriou J, Ceriani R: Expression of Human Mammary Epithelial (HME) antigens in primary cultures of normal and abnormal breast tissue. Int J Cancer 22: 655-661, 1978

14. Hilkens J, Buijs F, Hilgers J, Hageman Ph, Calafat J, Sonnenberg A, Van Der Valk M: Monoclonal antibodies against human milk-fat globule membranes detecting differentation antigens of the mammary gland and its tumours. Int J Cancer 34: 197-206, 1984

15. Hellman S, Harris JR, Canellos GP, Fisher B: Cancer, Principles and Practice of Oncology. JB Lippincott Company, Philadelphia, 1982, pp 922-924

16. Diem K, Lentner C (eds.): Scientific Tables; Statistical Methods. Ciba Geigy Ltd, Basel, Switzerland 1970, pp 146196
17. White CA, Dulbecco R, Allen R, Bowman M, Armstrong B: Two monoclonal antibodies selective for human mammary carcinoma. Cancer Res 45: 1337-1343, 1985

18. Menard S, Tagliabue E, Canevari S, Fossati G, Colnaghi MI: Generation of monoclonal antibodies reacting with normal and cancer cells of human breast. Cancer Res 43: 1295-1300, 1983

19. Croghan GA, Papsidero LD, Valenzuela LA, Nemoto T, Penetrante R, Chu TM: Tissue distribution of an epithelial and tumour-associated antigen recognized by monoclonal antibody F36/22. Cancer Res 43: 4980-4983, 1983

20. Croghan GA, Wingate MB, Gamarra M, Johnson E, Chu TM, Allen H, Valenzuela L, Tsukada Y, Papsidero LD: Reactivity of monoclonal antibody F36/22 with human ovarian adenocarcinomas. Cancer Res 44: 1954-1962, 1984

21. Burchell J, Wang D, Taylor-Papadimitriou J: Detection of the tumour-associated antigens recognised by the monoclonal antibodies HMFG-1 and 2 in serum from patients with breast cancer. Int J Cancer 34: 763-768, 1984

22. Ceriani RL, Blank EW, Rosenbaum EH, Zeev DB, Lowitz RS, Johansen L, Trujillo T: Diagnostic ability of different human milk fat globule antigens in breast cancer. Breast Cancer Res Treat 15: 161-174, 1990 